\title{
A SUGGESTED SOLUTION TO THE RIDDLE OF OBSCENITY
}

\author{
AtberkT B. Gerber $\dagger$
}

In his concurring opinion in Bantam Books, Inc. v. Sullivan, ${ }^{1}$ Mr. Justice Douglas relates an anecdote concerning a well-known Russian author who was banished to Siberia because of the "pernicious" character of a manuscript found by the police during a search of his home. The author had previously sent the article to a magazine for publication and while he was in Siberia it cleared censorship and was published in a widely circulated and well-respected magazine. ${ }^{2}$ This happened under the tyranny of the Russian Czars. One would like to believe that it could not happen in the United States today. Under our law of obscenity, however, it not only could happen, but variations on the theme occur with monotonous regularity.

"For the most part, the purpose of the criminal law is only to induce external conformity to rule," 3 and to accomplish its purpose the people, or at least the lawyers and judges, must be able to understand and apply the rule. But the criminal law of obscenity has become such a jungle of verbiage that no one could clearly set forth its rules of conduct.

Today authors, publishers, distributors, and vendors of books and periodicals have no guide for determining what is and what is not obscene. Under normal conditons a careful businessman employs able counsel, follows his advice carefully, and can look forward to remaining free of criminal charges. Such is not the case with respect to obscenity. In this twilight zone no one knows the answer in a given situation until the Supreme Court renders a decision. ${ }^{4}$ A startling example is

† B.S. 1934, LL.B. 1937, LL.M. 1942, University of Pennsylvania; M.A. 1941, George Washington University. Member, Pennsylvania and United States Supreme Court Bars.

1372 U.S. 58, 73-74 (1963), 51 CALIF. L. Rev. 620; cf. 110 U. PA. L. Rev. 1162 (1962) ; 8 UTAF L. Rev. 70 (1962).

2 The anecdote is quoted by Justice Douglas from KENNAN, StBerta AND THE ExILE SYSTEM 60 (1958).

3 Holmes, The Common Law 49 (Little, Brown \& Co. ed. 1881).

4 Justice Black refers to the situation as the "Court's becoming a Supreme Board of Censors-reading books and viewing television performances to determine whether, if permitted, they might adversely affect the morals of the people throughout the many diversified local communities in this vast country." Smith v. California, 361 U.S. 147 (1959). 
Henry Miller's Tropic of Cancer ${ }^{5}$ which is obscene in New York, Connecticut, ${ }^{7}$ Florida, ${ }^{8}$ Philadelphia, ${ }^{9}$ and elsewhere, ${ }^{10}$ but not obscene in California, ${ }^{11}$ Massachusetts, ${ }^{12}$ Wisconsin, ${ }^{13}$ and Chicago. ${ }^{14}$ Although a split in authority among the states is not unusual, it is unique for a Supreme Court decision to do no more than settle whether or not Tropic of Cancer is obscene under constitutional standards. ${ }^{15}$ The next book to use four-letter words or furnish overly candid descriptions of sexual acts may well have to go through the same three years of criminal and civil litigation as Tropic of Cancer. The reality of this problem will soon be apparent, with Tropic of Capricorn ${ }^{16}$ and Fanny Hill $^{17}$ waiting in the wings to become the subjects of litigation. ${ }^{18}$

What, if any, remedies can cure this distressing state of the law? Since reams have been written on the law of obscenity, ${ }^{19}$ the only ex-

5 (Grove Press ed. 1961).

6 People v. Fritch, 13 N.Y.2d 119, 192 N.E.2d 713, 243 N.Y.S.2d 1 (1963).

7 State v. Huntington, No. 24657, Super. Ct. Hartford County, Conn., 1962.

8 Grove Press, Inc. v. Florida, 156 So. 2d 537 (Fla. Dist. Ct. App. 1963).

9 Commonwealth v. Robin, No. 3177, C.P. Philadelphia County, Pa., 1962.

10 In Los Angeles, prior to clearance by the Supreme Court of California, it was held obscene in People v. Smith, App. Dep't Super. Ct. 1962, cert. granted, 373 U.S. 901 (1963) ; Besig v. United States, 208 F.2d 142 (9th Cir. 1953). In Maryland, the highest court reversed a conviction on other grounds but held that the book could be found obscene. Yudkin v. State, 229 Md. 223, 182 A.2d 798 (1962).

11 Zeitlin v. Arnebergh, 383 P.2d 152, 31 Cal. Rptr. 800 (Sup. Ct. 1963).

12 Attorney General v. The Book Named "Tropic of Cancer," 345 Mass. 11, 184 N.E.2d 328 (1962).

$13 \mathrm{McCauley}$ v. Tropic of Cancer, 20 Wis. 2d 134, 121 N.W.2d 545 (1963).

14 Heiman v. Morris, No. 61 S.19718, Super. Ct. Cook County, IIl., 1962.

15 See Note, 76 HARv. L. Rev. 54, 125 (1962): "As was the case in Roth, however, the opinions in Manual raise as many questions as they answer."

16 (Grove Press ed. 1961).

17 Cieland, Memoirs of a Woman of Pleasure (G. P. Putnam ed. 1963). First published in England circa 1749 and long regarded as a classic of eroticism, this is its first publication by a respectable publisher in the United States. The book also was the first subject of judicial censorship of literature in the United States. Commonwealth v. Holmes, 17 Mass. 336 (1821). In some respects we have now made the full circle.

18 Fanny Hill has taken the lead apparently because Capricorn is so similar to Cancer that prosecutors are awaiting final decision on the latter before going after the former. The early returns on Fanny Hill demonstrate the difficulties faced by the courts in reaching any type of agreement. In Larkin v. G. P. Putnam's Sons, 40 Misc. 2d 28, 243 N.Y.S.2d 145 (Sup. Ct 1963), Justice Marks granted a preliminary injunction restraining the defendants from "publishing, selling . . distributing" the book on the ground of legal obscenity. The court found the book "patently offensive and utterly without any social value.; Id. at 148. A month later, 40 Misc. $2 \mathrm{~d} 28$, 242 [sic] N.Y.S.2d 746 (Sup. Ct. 1963), Justice Klein vacated the injunction and entered judgment for the defendant, on the ground that "the book can in no manner whatsoever be characterized as 'patently offensive' when examined in the light of current community standards." Id. at 752.

19 Without endeavoring to furnish a complete bibliography, the following are suggested in their respective fields. AMrRrcan LIBRARY Ass'N, THE FIRST FreEdons (Downs ed. 1960) (a general survey of the problem-a complete collection of materials); ERNST \& SEAGLE, To THE PURE ... (1928) (history and background); Alpert, Judicial Censorship of Obscene Literature, 52 HARv. L. REv. 40 (1938) (history); Lockhart \& McClure, Literature, The Law of Obscenity, and the Constitution, 38 MrNN. L. Rev. 295 (1954); Lockhard \& McClure, Censorship of Obscenity: The Developing Constitutional Standards, 45 MINN. L. REv. 5 (1960) (a complete survey of the legal climate to mid-1960). 
cuse for another article on the subject is an endeavor to suggest some concepts which might eliminate the untenable posture that the law has adopted with respect to criminal obscenity. Before advancing these ideas, some of the historical underbrush should be cleared away.

\section{BACKGROUND \\ A. Common Law}

Most courts treat an obscenity offense as though it were an act malum in se, pernicious, and a deep affront to society. Under early common law, however, no offense was committed by the publication of a book or magazine containing sexual pictures or literature. In 1708, in Regina $v$. Read,$^{20}$ a gentleman was brought into criminal court for the publication of a book entitled Fifteen Plagues of a Maidenhead. The court held that such an act was "no offence at common law" but punishable only in the Ecclesiastical Courts. ${ }^{21}$ In that case, Judge Powell asserted the need for a law against such publications but refused to create one by judicial legislation. ${ }^{22}$ Unfortunately, the English courts changed the law twenty years later and decided that obscenity was punishable on the ground that it was an offense against religion and religion was part of the common law. ${ }^{23}$ The crime was subsequently incorporated into American jurisprudence. ${ }^{24}$

\section{B. Early Tests}

Regina $v$. Hicklin ${ }^{25}$ produced the first and classic test of what constitutes obscenity. Chief Justice Cockburn held the test to be "whether the tendency of the matter charged . . . is to deprave and corrupt those whose minds are open to such immoral influences, and into whose hands a publication of this sort may fall." ${ }^{2 B}$ The criterion, as can readily be seen, is as wide as the interpreter cares to make it. Under that test, much of what can be found today in almost any neigh-

20 Fortescue 98, 92 Eng. Rep. 777 (K.B. 1708).

21 Ibid.

22 "There is no law to punish it, I wish there were, but we cannot make law; it indeed tends to the corruption of good manners, but that is not sufficient for us to punish." Id. at 99, 92 Eng. Rep. at 777.

23 Rex v. Cur1, 2 Strange 788, 93 Eng. Rep. 849 (K.B. 1727). For detail see Straus, The Unspeakable CurL (1927).

24 Commonwealth v. Sharpless, 2 S. \& R. 91 (Pa. Sup. Ct. 1815), involved exhibition of an indecent picture which was held punishable even in the absence of statute on the authority of Rex v. Curl, supra note 23 ; Commonwealth v. Holmes, 17 Mass. 336 (1821) (a book).

25 L.R. 3 Q.B. 360 (1868).

26 Id. at 371 . 
borhood library was at one time or another banned as obscene. Theodore Dreiser's An American Tragedy, ${ }^{27}$ Boccaccio's Decameron, ${ }^{28}$ Casanova's Homecoming ${ }^{29}$ and The Well of Loneliness, ${ }^{30}$ and Lillian Smith's Strange Fruit ${ }^{\mathbf{3 1}}$ were all banned.

An important break in this test, which could ban anything from the Bible to the Koran, came in United States $v$. Dennett. ${ }^{32}$ A remarkable woman, Mary Ware Dennett, had written a pamphlet entitled The Sex Side of Life for her own children, aged eleven and fourteen. It was an excellent piece of work and there were many demands for it. It was published in the Medical Review of Reviews and reprinted in pamphlet form. For using the United States mails to supply requests for the pamphlet, Mrs. Dennett was convicted in the Southern District of New York. Judges Augustus N. Hand, Swan, and Chase of the Second Circuit reversed the conviction. The court in effect accepted the Hicklin test, yet decided that "an accurate exposition of the relevant facts of the sex side of life in decent language and in manifestly serious and disinterested spirit cannot ordinarily be regarded as obscene." ${ }^{33}$ This case laid the foundation for Judge Wolsey's significant decision in United States $v$. One Book Called "Ulysses," ${ }^{34}$ in which the issue was whether James Joyce's Ulysses was admissible into the United States despite customs prohibitions against obscene literature. The court cleared the book on the theory that it should not be judged by its effect upon "any person" into whose hands it may fall-the Hicklin test-, but rather that it must 'be tested by the court's opinion as to its effect on a person with average sex instincts-what the French would call l'homme moyen sensuel-who plays, in this branch of legal inquiry, the same role of hypothetical reagent as does the 'reasonable man' in the law of torts and 'the man learned in the art' on questions of invention in patent law." 35 The court also set forth the corollary rule that a work or book must be tested as an entirety, not with an eye to individual passages.

At this point the law rested for many years. Several jurisdictions refused to follow the enlightened view and continued to accept the

27 See Commonwealth v. Friede, 271 Mass. 318, 171 N.E. 472 (1930).

28 See Commonwealth v. McCance, 164 Mass. 162, 41 N.E. 133 (1895), in which a lower court conviction was reversed primarily for lack of specificity in the grand jury indictment.

29 People v. Seltzer, 122 Misc. 329, 203 N.Y. Supp. 809 (Sup. Ct. 1924).

30 People v. Friede, 133 Misc. 611, 233 N.Y. Supp. 565 (Magis. Ct. 1929).

31 Commonwealth v. Isenstadt, 318 Mass. 543, 62 N.E.2d 840 (1945).

3239 F.2d 564 (2d Cir. 1930).

33 Id. at 569.

345 F. Supp. 182 (S.D.N.Y. 1933), aff'd, 72 F.2d 705 (2d Cir. 1934).

$355 \mathrm{~F}$. Supp. at 184 . 
Hicklin test. ${ }^{36}$ There were attempts to offer other standards. Probably the most noteworthy attempt was that of Judge Bok ${ }^{37}$ who, faced with a case involving an indictment of a book seller for selling such material as the Studs Lonigan Trilogy, Faulkner's Sanctuary, and Caldwell's God's Little Acre, formulated the clear and present danger test. He suggested that if "the commission or the imminence of the commission of criminal behavior resulting from the reading of a book" could be shown, then that book could be regarded as obscene. ${ }^{38}$

\section{The Model Penal Code Test}

In 1957, the American Law Institute promulgated in the Model Penal Code a tentative model obscenity law. Unfortunately, it came at a time when the law was in a state of flux and the Institute's offering in the interest of clarifying a confused situation served only to compound the confusion. Without much clarification, the Institute carried its material over to a proposed final draft in 1962.

The ALI states: "Material is obscene if, considered as a whole, its predominant appeal is to prurient interest, that is, a shameful or morbid interest, in nudity, sex or excretion, and if in addition it goes substantially beyond customary limits of candor in describing or representing such matters." ${ }^{39}$ The major difficulty with this definition is that it serves to perpetuate the myth that obscenity is an absolute. As stated by Professor Gellhorn,

Those who urge increased repression of allegedly obscene books are of course convinced that "obscenity" can be identified. In reality, however, the word does not refer to a thing so much as to a mood. It is a variable. Its dimensions are fixed in part by the eye of the individual beholder and in part by a generalized opinion that shifts with time and place. ${ }^{40}$

After an attempt at definition which actually defines nothing, the ALI then says that the appeal "shall be judged with reference to ordinary adults unless it appears . . . to be designed for children

30 See, e.g., King v. Commonwealth, 313 Ky. 741, 233 S.W.2d 522 (1950); Commonwealth v. Isenstadt, 271 Mass. 318, 171 N.E. 472 (1930); State v. Becker, 364 Mo. 1079, 272 S.W.2d 383 (1954); Commonwealth v. Donadney, $167 \mathrm{~Pa}$. Super. 611,75 A.2d 440 (1950). 1949).

37 Commonwealth v. Gorden, 66 Pa. D. \& C. 101 (Q.S. Philadelphia County

38 Id. at 155.

39 Moder Penal Code §251.4(1) (Proposed Official Draft 1962).

40 Gellmorn, Individual Freedom and Governmental Restraints 55 (1956). 
or other specially susceptible audience." 41 In other words, the major thrust of the ALI's position is the intended audience. But at best the material is to be judged by its effect upon "ordinary adults." This is a typical "man on the street" test that would, if followed, reduce all art and literature to the level of "ordinary adults." However, the ALI test is not meant to go this far since it makes a broad range of evidence admissible, much of which necessarily must go beyond the effect upon an ordinary adult. ${ }^{2}$

The ALI also sets up an exception which completely undercuts the basic test-any person can disseminate material (otherwise obscene) so long as it is "non-commercial dissemination to personal associates . 43 Consequently, under the ALI test the benevolent lodge might have a stag film embodying hard-core pornography and no crime would be committed unless there was an admission charge. It scarcely seems appropriate to make the profit motive, ${ }^{44}$ at least in this country, the difference between a crime and a lawful act. In a comment the ALI implies that since science is uncertain whether the reading of erotica has any effect on behavior, we must follow a "conservative penal policy" ${ }^{45}$ and punish the dissemination of what might be regarded as obscenity. However, since we are interested, as the ALI indicates, primarily in potential criminal misbehavior, by what theory do we conclude that if an adult shows stag films in his home to a group of friends there will be no resultant criminal behavior unless he makes a charge for the privilege of viewing the film? Certainly, nowhere in this field has anyone suggested that this could possibly be a factor. ${ }^{4 \mathrm{~B}}$

41 Model Penal Code \$251.4(1) (Proposed Official Draft 1962). The Supreme Court squarely rejected the Code on this point in Manual Enterprises, Inc. v. Day, 370 U.S. 478 (1962), in which the material was unquestionably designed to appeal to the prurient interests of homosexuals. For example, the Government introduced evidence that the publisher endeavored to obtain photographs of males who were "'truck driver types' already cleaned up, showered and ready for bed." Record, p. 89

(Government's exhibit G.); see 16 VAND. L. Rev. 251, 257 (1962).

42 See Model Penal Code \$251.4(4) (Proposed Official Draft 1962).

43 Id. $\$ 251.4$ (3) (b).

44 The final draft of $\$ 251.4(3)$ (b) refers to "non-commercial dissemination." In the early drafts this was described as dissemination "not for gain." See MODEL PENAL CoDE $\$ 207.10$ (Tent. Draft No. 6, 1957). Presumably they are equivalent, since the comments indicate no intention to make a change at this point except perhaps as a "minor verbal change." See Model PENAL CODE $\$ 251.4$, comment at 240 (Proposed Official Draft 1962).

45 Model Penal Code $\$ 207.10$, comment 1, at 7 (Tent. Draft No. 6, 1957).

46 There is language in State v. Jacobellis, 173 Ohio St. 22, 28, 179 N.E.2d 777,

781 (1962), that could be stretched to support the theory:

Les Amants (The Lovers) was not hard-core pornography, i.e., filth for filth's sake. It was worse. It was filth for money's sake. The producers, distributors and exhibitors evidenced so little responsibility in connection therewith that they have no right to assert constitutional guarantees which require a high degree of responsibility from those who seek their protection. This is especially apropos of the First and Fourteenth Amendments to the Constitution of the United States. 
In general, the ALI analysis adds little to the present state of the law but can, and has, ${ }^{47}$ confused those endeavoring to follow its suggestions. ${ }^{48}$

\section{The Modern Test}

In Roth $v$. United States, ${ }^{49}$ the Supreme Court theoretically created a new test for obscenity. The Court held that "obscene material is material which deals with sex in a manner appealing to prurient interest," 50 which the Court defined to be "material having a tendency to excite lustful thoughts." 51 Or, stated another way, "whether to the average person, applying contemporary community standards, the dominant theme of the material taken as a whole appeals to prurient interest." ธ2

To attorneys and judges who make daily decisions about whether a book, photograph, magazine, or article is obscene, this test is unsatisfactory. Are "contemporary community standards" those prevalent in the local area, the state, or the United States? ${ }^{\text {s3 }}$

Although the Court failed to establish a satisfactory test of what constitutes obscenity, it did set forth two criteria necessary to sustain the constitutionality of a conviction. These are that the material must be treated as a unit rather than judged on the basis of isolated or individual parts or passages, and that it must be examined with regard to its effect upon average or normal adults and not on how it might impinge upon the young or immature. In Manual Enterprises, Inc. $v$.

47 The Supreme Court in Roth purported to adopt many of the American Law Institute ideas. However, see Mr. Justice Harlan's opinion in which he indicates the Court's confusion on this point. Roth v. United States, 354 U.S. 476, 499-500 (1957). Schwartz, Criminal Obscenity Laze: Portents From Recent Stureme Court Decisions and Proposals of the American Law Institute in the Model Penal Code, 29 PA. B.A.Q. 8, 11 (1957), says that the Supreme Court "may have been trying to bring existing law up to the level of the Model Penal Code by the tour de force of declaring that it was already there."

48 For the best justification for the position of the ALI see Schwartz, Moral Offenses and the Penal Code, 63 Colum. L. Rev. 669, 677-81 (1963). The author states that the Institute is endeavoring to change the normal crime from one of the "sin of obscenity" to one of commercial exploitation of the "weakness for titillation by pornography." Id. at 677. From the viewpoint of a practitioner the ALI introduces more uncertainties than it eliminates.

49354 U.S. 476 (1957). For an analysis see Kalven, The Metaphysics of the Law of Obscenity, in 1960 Supreme Court Review 1 (Kurland ed.).

50354 U.S. at 487.

51 Id. at 487 n.20.

$52 I d$. at 489.

53 For a thorough critique of the Roth text see Lockhart \& McClure, supra note 19, at 49-58. Manual Enterprises, Inc. v. Day, 370 U.S. 478, 488 (1962), indicates that the standard for obscenity in the mails "is a national standard of decency." 
$D a y,{ }^{54}$ at least a part of the Supreme Court added an additional and significant criterion: that the material be patently offensive.

Thus, the Court's statements on obscenity make it appear that obscene material is an appeal "to prurient interests," which, freely translated, in all probability means that it relates to the sexual or the scatalogical; the material must be considered as a whole; it must be patently offensive. Testing any specific item against this three-pronged test, can a lawyer decide whether it is obscene? The answer must be in the negative. Thus, attention must turn to the pragmatic, i.e., what the Supreme Court has done rather than what it has said.

\section{The Conduct of the Supreme Court}

Justices Black and Douglas have asserted that all publications are entitled to constitutional protection and that punishment should not be permitted for obscenity..$^{5 \overline{5}}$ The position of these two Justices simplifies the problem considerably since it would eliminate the legal concept of obscenity. For most of the Justices mere nudity does not constitute obscenity; the Court reversed the Ninth Circuit's decision that a collection of nudist and art student publications containing nude photographs was obscene. ${ }^{56}$ The pictures in that case involved noncultist nudity and the normal argument that the nudist magazines were espousing an idea was probably absent, for, as the trial court stated: "although an avowed purpose of the books is to explain the nudist movement, its principles and its practices, there are relatively very few photographs of the mixed groups of all ages which ordinarily would be found in a nudist park. The great preponderance of the illustrations depicts

54370 U.S. 478 (1962). Mr. Justice Harlan announced the decision of the court. Mr. Justice Stewart concurred in the opinion. Mr. Justice Black concurred in the result without opinion. The Chief Justice and Justices Brennan and Douglas concurred in the reversal but on the ground that the Postmaster General had no legal authority to make nonmailability determinations at all. Mr. Justice Clark dissented. Justices White and Frankfurter took no part in the case. For discussions see Rossman, Review of Recent Supreme Court Decisions, 48 A.B.A.J. 1071, 1073 (1962); The Supreme Court, 1961 Term, 76 HARv. L. REv. 54, 125-30 (1962); 27 AlbANy L. Rev. 127 (1963) ; 29 Brooklyn L. Rev. 325 (1963); 24 Mont. L. Rev. 65 (1962); 17 Rutgers I. Rev. 213 (1962); 30 TenN. L. Rev. 291 (1963) ; 16 VAND. L. Rev. 251 (1962). See generally Fleishman, Obscentity and Post Office Censorship, 22 LAW in TRANSITION 222 (1963).

55 Roth v. United States, 354 U.S. 476, 509 (1957) (Douglas \& Black, JJ., concurring. These Justices suggest a possible exception when the material "has an impact on action that the government can control." Id. at 511. This is close to Judge Bok's position in Commonwealth v. Gordon, 66 Pa. D. \& C. 101 (C.P. Philadelphia County 1949). Justice Douglas continues his near-the-extreme position in Smith v. California, 361 U.S. 147, 167-69 (1959), but Justice Black goes all the way-that there cannot be constitutional censorship of obscenity. Id. at 157-59. The Chief Justice indicates a sympathetic view since he believes that the primary problem is: "The conduct of the defendant" rather than the "obscenity of a book or picture." Id. at 495 .

50 Mounce v. United States, 355 U.S. 180 (1957), reversing 247 F.2d 148 (9th Cir. 1957). 
shapely, well-developed young women appearing in the nude, mostly in front exposures." 57 The principle that nudity alone cannot be equated with obscenity was underlined by the Court in Sunshine Book Co. v. Summerfield, ${ }^{58}$ in which the pictures went even further, since they showed both male and female genitalia and pubic hair. The Court has also held that neither magazines and pictures deliberately intended to excite homosexuals ${ }^{59}$ nor a motion picture entitled The Game of Love containing "a series of illicit sexual intimacies and acts" and a graphic portrayal of sexual relations, seductions, and nudity "with nothing omitted except those sexual consummations which are plainly suggested and meaningfully omitted" ${ }^{60}$ is obscene. ${ }^{61}$ In only one of these cases did the Court reverse and remand for reconsideration by the lower court. $^{62}$ In all the rest the Court reversed and decided the case.

One general interpretation of the three-cornered test plus the actual decisions of the Court is that today only hard-core pornography is obscene. ${ }^{63}$ To some extent this only changes the form of the question because we must now ask what is "hard-core pornography"? ${ }^{\text {ot }}$ Nevertheless, a considerable amount has been gained in the solution of the problems facing attorneys who must decide matters for pub1955).

57 United States v. 4200 Copies Int'l Journal, 134 F. Supp. 490, 494 (E.D. Wash.

58355 U.S. 372 (1958) (per curiam), reversing 249 F.2d 114 (D.C. Cir. 1957), affirming 128 F. Supp. 564 (D.D.C. 1955). 1957).

59 One, Inc. v. Olesen, 355 U.S. 371 (1958), reversing 241 F.2d 772 (9th Cir.

60 Times Film Corp. v. City of Chicago, 244 F.2d 432, 436 (7th Cir. 1957), reversed, 355 U.S. 35 (1958).

61 Times Film Corp. v. City of Chicago, 355 U.S. 35 (1958), reversing 244 F.2d 432 (7th Cir. 1957).

62 In Mounce v. United States, 355 U.S. 180 (1957), the Court "reversed and remanded" for further consideration.

63 Lockhart \& McClure, Censorship of Obscenity: The Developing Constitutional Standards, 45 Minn. L. Rev. 5, 60 (1960) ; Note, 12 De Paul L. Rev. 103 (1962). The court so held in People v. Richmond County News, Inc., 9 N.Y.2d 578, 175 N.E.2d 681,216 N.Y.S.2d 369 (1961) (constitutional obscenity is only ". . . what may properly be termed "hard-core pornography" "). See also McClure, Obscenity and the Laze, 56 AM. LIBRARY A. BuLL. 806, 810 (1962) ("Obscenity censorship is restricted by the federal constitution to hard core pornography. All else enjoys constitutional protection."); 76 HaRv. L. REv. 1498 (1963); Note, 39 N.D.L. REv. 308, 312-13 (1963).

64 There have been many attempts to define hard core pornography. See KRoNhausen, Pornography and the Law 178-240 (1959); Lawrence, Pornography AND OBSCENITY 74-77 (1953) ("Pornography is the attempt to insult sex, to do dirt on it.") ; Mead, Sex and Censorship in Contemporary Society, in NEW WoRLD WRITING 7, 23 (1953) ("Pornography does not lead to laughter; it leads to deadly serious pursuit of sexual satisfaction divorced from personality and from every other meaning.").

This writer believes that the distinction between "hard-core pornography" and "soft-core" or non-hard-core is a pleasant exercise in semantics but will never have any value in the law. 
lishers, courts that must decide cases as a matter of constitutional judgment, and district attorneys who must make a preliminary judgment finding.

No form of nudity in reasonably good taste will be found obscene. ${ }^{65}$ No serious writing would seem to be obscene regardless of how intimately the details of sex are verbalized, provided that offensive four letter words are not employed. ${ }^{66}$ That is not to say that the use of the four letter words ipso facto renders any item obscene. On the contrary, it is probably accurate to say that the use of these is irrelevant. However, a recent decision of the New York Court of Appeals ${ }^{67}$ gives pause to a conclusion that would ignore the existence of four letter words. It is one of the fields still in the no-man's land of obscenity. Finally, it is difficult to conceive of any motion picture, not patently offensive, being regarded as constitutionally obscene. After the Supreme Court reversed the New York Court of Appeals in Lady Chatterly's Lover, ${ }^{68}$ it was accused of "endorsing adultery" 69 and joining a world conspiracy to subvert the morals of our land. ${ }^{70}$ But the Court survived and struck the cruelest blow of all to the Comstocks-the Justices added a constitutional requirement that punishment in obscenity cases be limited to defendants who had knowledge of the obscene contents of the material. ${ }^{\mathbf{1}}$

\section{OBscene to Whom?}

Assuming a workable test for obscenity, an important question is who applies the standard. For many years it was assumed that the question of obscenity was a question of fact to be found by the jury, ${ }^{72}$

65 Nudist motion pictures have been held not obscene. Excelsior Pictures Corp. v. City of Chicago, 182 F. Supp. 400 (N.D. Ill. 1960); Commonwealth v. Moniz, 338 Mass. 442, 155 N.E.2d 762 (1959); cf. Moded Penal Code $\$ 207.10$, comment 8 (Tent. Draft No. 6, 1957).

66 See Grove Press, Inc. v. Christenberry, 175 F. Supp. 488 (S.D.N.Y. 1959).

67 People v. Fritch, 13 N.Y.2d 119, 126, 192 N.E.2d 713, 717, 243 N.Y.S.2d 1, 7 (1963) (dictum).

68 Kingsley Int'1 Pictures Corp. v. Regents of the Univ., 360 U.S. 684 (1959).

${ }^{69}$ Congressman Clare E. Hoffman (R., Mich.) in N.Y. Times, Sept. 2, 1959, p. 31 , col. 8 .

70 Benedict, The "Lady Chatterley's Lover" Case, American Mercury, Jan. 1960 , p. 3.

71 Smith v. California, 361 U.S. 147 (1959).

72 See People v. Williamson, 24 Cal. Rptr. 734, 735 (Dist. Ct. App. 1962). This produced an interesting problem such as that presented in Commonwealth v. Friede, 271 Mass. 318, 171 N.E. 472 (1930), involving Dreiser's An American Tragedy, in which the court refused to permit the introduction of the entire book into evidence on the theory that it was too long to have it read to the jury. That enough copies might be introduced so that the jurors could read it themselves was not considered. 
or in administrative proceedings by the fact finder. ${ }^{73}$ In these situations there was little room for subtlety, and a test, of necessity, had to be broad enough to be capable of complete comprehension, application, and conclusion by the man on the street. It was the type of test that handled material with a shovel rather than tweezers.

Happily for those interested in freedom from censorship, that era is gone. It has been clear for decades that the Supreme Court will not permit constitutional rights to be invaded by the guise of a conclusory finding of fact. As stated by Mr. Justice Frankfurter, "especially in cases arising under the Due Process Clause is it important to distinguish between issues of fact that are here foreclosed and issues which, though cast in the form of determinations of fact, are the very issues to review for which this court sits." ${ }^{74}$ And in Roth Mr. Justice Harlan stated:

I. do not think that reviewing courts can escape this responsibility by saying that the trier of facts, be it a jury or a judge, has labeled the question matter as "obscene", for, if "obscenity" is to be suppressed, the question whether a particular work is of that character involves not really an issue of fact but a question of constitutional judgment of the most sensitive and delicate kind. ${ }^{\mathbf{T}}$

This theory is now well accepted and the courts are deciding obscenity questions without endeavoring to escape responsibility by sending them to a jury. ${ }^{76}$ Although the matter is for the courts and there is a string of precedents from the Supreme Court, the state of the law, as exemplified by the Tropic of Cancer cases, is one of considerable confusion.

\section{The Tropic of Cancer CASES}

Tropic of Cancer by Henry Miller was the first book of a serious nature to be published in light of the climate created by the Supreme Court in its per curiam decisions of 1957-1958. The Grove Press,

73 See Paul \& Schwartz, Federal Censorship (1961); Paul, The Post Office and Non-Mailability of Obscenity: An Historical Note, 8 U.C.L.A.L. REv. 44 (1961); Schwartz, Obscenity in the Mails: A Comment on Some Problems of Federal Censorship, 106 U. PA. L. REv. 214 (1957).

74 Watts v. Indiana, 338 U.S. 49, 51 (1949) (opinion of Frankfurter, J.). The obscenity cases technically arise under the Due Process clause. In Gitlow v. New York, 268 U.S. 652 (1925), the Court brought the protections of the first amendment under the wing of the fourteenth and thereby set the stage for subsequent invalidating of state obscenity statutes by the United States Supreme Court. See Joseph Burstyn, Inc. v. Wilson, 345 U.S. 495 (1952).

75 Roth v. United States, 354 U.S., 476, 497-98 (1957) (Harlan, J., dissenting).

76 See People v. Richmond County News, Inc., 9 N.Y.2d 578, 175 N.E.2d 681, 216 N.Y.S.2d 369 (1961) ; cases cited notes 11-13 supra; Bunis v. Conway, 17 A.D.2d 207, 234 N.Y.S.2d 435 (1962). But see Tralins v. Gerstein, 151 So. 2d 19 (D. Ct. App. Fla. 1963). 
Inc. decided that no book of serious intent and purpose could be regarded as obscene. ${ }^{77}$ Consequently, Tropic of Cancer was published in hard cover and distributed throughout the United States and subsequently reprinted in soft cover for full distribution on almost every newsstand and drug store in the country.

The book was first published in Paris in 1934 and for a long time was regarded as beyond the pale in the United States. However, it was frequently brought back into the United States by both literary scholars and collectors of what was then regarded as pornography. The book has no plot and it is primarily a series of partially connected episodes in the life of an American living in Paris in the early 1930's. The major problem to the American mores is that in describing sex episodes the author omits no detail and employs earthy Anglo-Saxon four-letter words without hyphens or asterisks.

The book was attacked throughout the country and received mixed reactions in the lower courts. ${ }^{78}$ However, it was held not obscene by the courts of last resort of Massachusetts, Wisconsin, and California. ${ }^{79}$ It appeared that the courts were well on the way to rounding out the definition of obscenity so that an attorney could confidently assert that no book of a serious nature could be regarded as constitutionally obscene. The Supreme Judicial Court of Massachusetts, by a four-to-three decision, decided: "It is not relevant that we think that the book at many places is repulsive, vulgar, and grossly offensive in the use of four letter words, and in the detailed and coarse statement of sexual episodes." 80 The court concluded that since the book "has serious purpose" it cannot be held obscene because it falls within the protection of the first amendment. The majority specifically stated for purposes of any further appeal that there should be "no doubt that this case has been decided solely upon the Federal issue." ${ }^{81}$ The following year the book reached the Supreme Court of Wisconsin, which, in a rather similar decision, ${ }^{82}$ also found the book

77 Affidavit of Barney Rosset, principal editor of Grove Press, Inc., in Grove Press, Inc. v. Callissi, 208 F. Supp. 580 (D.N.J. 1962): "Grove Press concluded that there was no longer any legal impediment to the publication of Tropic of Cancer in this country."

78 See cases cited notes $7,9,10,14$ supra.

79 Cases cited notes 11-13 supra.

80 Attorney General v. Book Named "Tropic of Cancer," 184 N.E.2d 328, 334 (Mass. 1962).

81 Id. at 335. A minority, including the Chief Justice, filed a vigorous dissent on the theory that these Justices could not believe the thesis that a book pitched at such a "low level" could possibly become "endowed with constitutional protection." Id. at 336 .

82 McCauley v. Tropic of Cancer, 121 N.W.2d 545 (Wis. 1963). The minority followed the dissent in Massachusetts, expressing the thought that because the book was "saturated with filth in its substance and in its expression" it had no right to constitutional protection. Id. at 556. 
entitled to constitutional protection. The majority decided that because the book commanded serious attention as a literary work it could not be found obscene. When, six weeks later, California joined the parade with a thoughtful, well-reasoned, and unanimous decision, ${ }^{83}$ the rule could almost be said to have been "well established" that a serious piece of literature could not possibly be obscene.

Then the New York Court of Appeals handed down a surprise decision in New York $v$. Fritch ${ }^{84}$ Faced with a truly difficult set of facts, the court found the book obscene. In Wisconsin, Massachusetts, and California the cases had arisen on declaratory judgments. It would seem to have been relatively simple for a court in an abstract problem involving no punishment to have found the book obscene. The New York case, however, involved a criminal trial in which the defendants were convicted for a violation of the state penal law. After conviction by a jury, the county court reversed the conviction and dismissed on constitutional grounds. On appeal, the majority of the court reversed and remanded for a new trial on the ground that the book was not entitled to constitutional protection. The majority opinion held the book obscene regardless of whether it has "substantial literary merit." Significantly, the court stated that it would "not adopt a rule of law which states that obscenity is suppressible but that well-written obscenity is not." 85

A major fallacy of the opinion is the assumption that obscenity is an absolute. Regardless of who writes it, for what purpose, in what context, in what place or time, the New York court believes that it can detect obscenity. The court stumbled into a second fallacy when it declared that its concern was whether the material appeals to the prurient interest of the average person in the contemporary community. However, it is submitted that the "average person" test should not refer to the man on the street but rather, as Judge Woolsey in Ulysses intended, to the equivalent of the patent law's "man learned in the art." 86 In the obscenity area this would be a man learned in the particular field under consideration. In literature it would be the critic, the professor, the publisher. In the movie field it would be the

83 Zeitlin v. Arnebergh, 383 P.2d 152, 31 Ca1. Rptr. 800 (Sup. Ct. 1963).

84 New York v. Fritch, 13 N.Y.2d 119, 192 N.E.2d 713, 243 N.Y.S.2d 1 (1963).

85 Id. at 126, 192 N.E.2d at 717, 243 N.Y.S.2d at 7. One is reminded of the Massachusetts decision on Dreiser's American Tragedy, Commonwealth v. Friede, 271 Mass. 318, 171 N.E. 472 (1930), in which the court states: "[E] ven assuming great literary excellence, artistic worth and an impelling moral lesson in this story, there is nothing essential to the history of the life of its principal character that would be lost if these passages were omitted which the jury found were obscene, indecent and manifestly tending to corrupt the morals of youth." Id. at 321, 17i N.E. at 474 . 1933).

${ }^{86}$ United States v. One Book Called "Ulysses," 5 F. Supp. 182, 184 (S.D.N.Y. 
reviewer, the producer, the craftsman. But properly it should not be the man on the street. ${ }^{87}$ The New York court, however, specifically rejected this concept, stating:

It does not follow, then, that because an alleged work of literature does not appeal to the prurient interest of a small group of intellectuals that it is not obscene under the prurient interest, or for that matter any other legal test of obscenity. This would permit the substitution of the opinions of authors and critics for those of the average person in the contemporary community. The fact that a few literary figures have commented favorably on this book and have lent it their prestige does not expunge from its pages the flagrantly obscene and patently offensive matter which dominates the book as a whole. ${ }^{88}$

This is a curious reversal of logic. Just as a publication cannot be held obscene simply because it has an unusual effect upon a particular segment of the community, "such as children, the pious, or the prudish," this court would not test the absence of obscenity "by the lack of impact it has on the literary community." 80

\section{Variable Obscenity}

Obscenity, the New York Court of Appeals notwithstanding, is not an absolute; it has many variables. The major variable is the mode of communication being employed. There is little doubt that a nudist cinema admitting adults only is today constitutionally protected. However, a life size still color photograph of one of the nudes in the same picture plastered in front of the theatre would probably not be protected in most courts.

87 A case which clearly demonstrates the fallacy of using the literal "average man" test is State v. Mahoning Valley Distrib. Agency, 116 Ohio App. 57, 186 N.E.2d 631 (1962), in which the court held a book, Sex Life of a Cop, obscene, rejecting "expert" testimony, stating:

The evidence submitted in this case is voluminous ( 1,063 pages) and consists of long drawn out testimony by "experts." None of these witnesses qualified, in our opinion, as experts on the prurient interests of the average person in the community. Each may have been an "expert" in his own field, such as teaching, preaching, etc. But we strongly doubt that they were experts in the field in which they were giving "expert" testimony. At best, they were giving their own opinions, gathered in the limited field of their own professions and experience as to what they thought. The average policeman, judge, or general medical practitioner would probably have come much closer to being an expert.

Id. at 59, 186 N.E.2d at 632 .

8813 N.Y.2d at 125, 192 N.E.2d at 717, 243 N.Y.S.2d at 7.

80 Ibid. 
The reason for the difference goes back to basic principles. Every decision involving obscenity demands a judicial balancing of interests. ${ }^{90}$ On the one hand is the interest in the freedom of communication of ideas specifically protected by the first amendment. On the other hand are the rights of individual people to be protected, if they so desire, from the distasteful impact of material which is offensive to their sense of sexual morality. There are, of course, subsidiary protections of other interests. Since some people believe that certain sexual material may damage the moral fiber of youth, ${ }^{91}$ parents and those in charge of youth have the right to keep their charges free from what they may regard as the corrupting or debasing influence of certain types of sexual literature or pictures. No attorney would argue today that there is a constitutional right to sell pictures of copulating nudes to high school children. $^{92}$ Daily newspapers of general circulation, the billboard companies, and others who spread their wares before the general public, have a duty to refrain from spreading material which in the normal course of events must be forced before the eyes of many segments of the community who would be deeply offended by it. However, a specialized magazine such as the typical "girlie" magazine, the nudist magazine, the magazine for homosexuals, or any book, for that matter, presents a totally different problem. No woman of delicate sensibilities will be offended if she does not seek out the material. Children may not have it if their parents are sufficiently protective. ${ }^{03}$ It is both simple and constitutional to prohibit the dissemination of such material to children. In the movie field, it is certainly permissible to make it a crime for a proprietor to admit a minor or anyone under a certain

${ }^{90}$ In McCauley v. Tropic of Cancer, 121 N.W.2d 545 (Wis. 1963), the majority used a "balancing of factors" to find nonobscenity. However, the factors were not those suggested in the text above. The court weighed the material under consideration against "the purposes, ideas or artistic quality of the work." Id. at 550.

91 See Cairns, Paul \& Wishner, Sex Censorship: The Assumptions of AntiObscenity Laws and the Empirical Evidence, 46 MrNn. L. Rev. 1009, 1038-39 (1962). A fine summary of the state of scientific evidence on this point is found in a concurring opinion by Judge Jerome Frank in United States v. Roth, 237 F.2d 796, 812-19 (2d Cir. 1956), aff'd, 345 U.S. 476 (1957). See also MCKeon, Merton \& Gelimorn, THE FREEDOM To READ 71-78 (1957). It is surprising that although the proponents of the idea that sexual material causes juvenile delinquency are both loquacious and convinced, see, e.g., Hearings on Obscene Matter Sent Through the Mail Before the Subcommittee on Postal Operations of the House Committee on Post Office and Civil Service, 87th Cong., 1st Sess. passim (1962), there is a dearth of evidence that the a priori assumptions of the proponents have any scientific basis. Unquestionably there are a great many factors causing juvenile delinquency-some of them surprising. See, e.g., Litwack, An Examinzation of Ten Significant Differences Between Juvenile Recidivists and Non-Recidivists, 55 J. OF ED. RESEARCH 132 (1961).

92 See Mathews v. State, 99 So. 2d 568 (Fla. 1957), cert. denied, 356 U.S. 918 (1958) (defendant convicted of showing obscene pictures to a 12-year-old girl).

93 "An alert parent will find sensible means of keeping her children from reading books for which they are not yet ready-without resorting to bans and boycotts." Goodman, How To Deal With Obscene Books, Redbook, Nov. 1957. 
mature age for certain types of shows-a matter which could be decided by the state legislature..$^{94}$

The adoption of such a solution would, in effect, eliminate obscenity as applied to any adult media not embodied in a form which in the normal course of events would impinge upon broad segments of the community without individual consent. We all must read the newspapers, but we do not have to read Tropic of Cancer..$^{95}$ We cannot escape the billboards, but we do not have to go into the movies if we do not like nudist films.

This theory, carried to the extreme, brings us to the problem of "hard-core pornography." We have the French postcards and stag films to consider. The pure and unadulterated acceptance of the test submitted would also entitle these to constitutional protection. It is doubtful whether most courts are ready for this step. Yet, in a recent case a court faced the problem and did not flinch. In United States $v$. 31 Photographs, ${ }^{96}$ the Kinsey Institute had endeavored to import for scientific study photographs unquestionably of the hard-core pornography type. The Bureau of Customs refused to permit their importation because if anything was "obscene" under the Tariff Act these photographs were. However, the court ruled against the Department of Justice, which did not take an appeal. The decision is regarded as an example of the theory of variable obscenity, i.e., that obscenity is really a descriptive characteristic referring to the "chameleonic quality of material that changes with time, place, and circumstances." ${ }^{97}$ It is contrasted, of course, to a theory that "obscenity is an inherent characteristic of obscene material, so that material categorized as obscene is always obscene at all times and places and in all circumstances . . . " 98 The theory of variable obscenity and the decision in Kinsey are directly at variance with the decision of the New York Court of Appeals. But it is in direct line with the test here espoused-

94 See Note, "For Adults Only": The Constitutionality of Govermmental Film Censorship by Age Classification, 69 Yare L.J. 141 (1959). Such legislation must be drawn carefully and contain reasonable limitations. An automatic age 21 limitation may be unreasonable. Cf. Paramount Film Distrib. Corp. v. City of Chicago, 172 F. Supp. 69 (N.D. IIl. 1959).

95 In the $M c$ Canley case, the court comes close to using this point as a criterion for decision, saying that much of the language in the book was offensive and the words were classified according to the dictionary as vulgar or obscene. The court concludes: "Although some of these words would not be tolerated in our society if inflicted on unwilling listeners, an offended reader need only close the book in order to escape." 121 N.W.2d at 551.

96156 F. Supp. 350 (S.D.N.Y. 1957), 7 KaN. L. REv. 216 (1958).

97 Lockhart \& McClure, Censorship of Obscenity: The Developing Constitutional Standards, 45 MINN. L. REv. 5, 68 (1960).

88 Ibid. 
that in order to remove any form of communication from the general constitutional protection, the harm threatened ${ }^{99}$ must be extreme.

Under Kinsey, we must conclude that in the abstract even French postcards and stag films are not obscene. ${ }^{100}$ A sexologist club or a psychiatrists' association exhibiting stag films for purposes of analysis or testing pulse and pressure effect or post-associative ideas should be protected. A backroom showing for high school youths, however, can constitutionally be banned. What of the benevolent lodge which features such a film to attract membership to an otherwise dull meeting? It is dubious whether there is any overriding public interest which demands that the leaders of the organization be punished. Those who attend do so with full knowledge of what to expect, and those who object can stay away. No one has ever demonstrated that exposure to the stimulus of a sex film has caused anyone to commit rape or any other misconduct. There is much loose talk that it "can or might" do so, but whatever scientific evidence there is on the subject points in the other direction.

Although there are many respected authorities who believe that there should be no such doctrine as obscenity, ${ }^{101}$ it may be that the

99 Not the degree of the obscenity (if "degree" is a proper word for measuring relativity of obscenity).

$100 \mathrm{~A}$ group no less distinguished than the American Law Institute reaches the same conclusion but bases its decision upon the commercial nature of the exhibition. In this Article the suggested criterion is: Does the "obscenity" impinge involuntarily upon any person or group? The ALI asks, does it do so commercially? MoDEL Penal Code \$251.4(3) (Proposed Official Draft 1962).

101 For example, Justices Black and Douglas, see Roth v. United States, 354 U.S. 476, 508-14 (1957); Smith v. California, 361 U.S. 147, 155-60, 167-69 (1959). One of the best arguments against any form of censorship, either before or after the fact, is found in HaNey, CoMSTOCKery IN AMERICA 65 (1960):

Many-sided though it is, censorship possesses the one unifying emotional response of fear-fear of a world which would, if we faced it, threaten us with the task of becoming individual human beings. Our blushes and smirks and self-righteous denunciations of four-letter words, lewd pictures, and all the other paraphernalia of obscenity and pornography are little more than the attempt to feel noble when we are really being absurd. And we pass on through generations this legacy of fear. All the muck and dirt which pornographic literature and photography can pour out into our bookstores or onto our newsstands is trivial beside the real damage to the human soulthe systematic production of frightened and inept men and women which goes under the name of censorship.

$I d$. at 65 . See the incisive opinion by Judge Shapiro, People v. Birch, 243 N.Y.S.2d 525, 532-33 (Sup. Ct. 1963), in which the court, after analyzing a series of books which deal with "The March from Puberty to Prostitution," concludes:

To censor these books, by law, would be flowering the seed of the repression of free expression. If books such as these are to be suppressed, it should not be done by law, but by the starvation of those who write and distribute them through the failure of the public to purchase them. Education, and not judicial legislation, is the answer. In the words of Plato (The Republic, Ch. XI) "It would be silly, I think, to make laws on these matters." Voluntary censorship, exercised by the would-be purchaser of such material, is the essence of a free society, - a society which has more to lose from unbridled censorship than from prohibiting the publication of "gamy" books. That is one of the main differences between worlds that are open and worlds that are 
country is not ready for that extreme position. If not, we should explore the interest that is protected when a court holds an item to be obscene. No responsible court, in modern times, has held or asserted that an obscene item is dangerous because it might incite the reader or viewer to perform a criminal act. ${ }^{102}$ The only interest left to be protected, therefore, is the individual's right to be free from involuntary contact with morally offensive material. There are, of course, those who would protect their neighbor's and everyone else's morals. But this is certainly going too far. As Professor Henkin says, "it is time to begin to examine-if only in order to justify-the right of constitutional government to legislate morality which has no secular, utilitarian, or social purpose." ${ }^{103}$. If prohibition of the dissemination of material on the ground of obscenity is based on the protection of someone's morals, the significance of that interest can best be evaluated in the balancing of interests test. As a leading trial lawyer in this field has observed, what is freely permitted on the stage or in an expensive hard cover book will be censored in the movies or in a cheap paperback. He explains, "The assumption of the censor is that if a man can afford to spend $\$ 8.50$ for a theatre ticket, then he's sophisticated and won't be corrupted by what he sees on the stage. But the people who see films in a neighborhood movie-house, where the price of admission may be a dollar, are presumably in need of protection." 104

In further demonstration that obscenity is a variable, we have only to point to the factor of time. It might be said that time cures all obscenity. Judge Learned Hand, more than half a century ago, significantly observed this point while reluctantly sustaining an indictment for the publication of a book that today would scarcely cause the

closed. In the final analysis we mitust trust in the good sense of the people. They should be the sole judges of whether they are going to be literary gourmets, gourmands, or gluttons for what is "one reader's obscenity is another's artistry" (N.Y. Times, editorial, 8/24/63).

Compare the fear of the intellectual that art can never be uncensored. Jenkins, The Laisser-Faire [sic] Theory of Artistic Censorship, 5 J. OF THE HISTORY OF IDEAS 71 (1944).

102 See Judge Jerome Frank concurring in United States v. Roth, 237 F.2d 796,

812 (2d Cir. 1956), aff'd, 345 U.S. 476 (1957):

To date there exist, I think, no thorough-going studies by competent persons which justify the conclusions that normal adults' reading or seeing of the "obscene" probably induces anti-social conduct. Such competent studies as have been made do conclude that so complex and numerous are the causes of sexual vice that it is impossible to assert with any assurance that "obscenity" represents a ponderable causal factor in sexually deviant adult behavior.

Also, Judge Frank quoting New York City's famous Mayor Walker to the effect that "he had never heard of a woman seduced by a book."

103 Henkin, Morals and the Constitution: The Sin of Obscenity, 63 Colun. I. Rev. 391, 414 (1963).

104 The Independent, Oct. 1963, p. 1, col. 3, quoting Ephraim London. 
lifting of an eyebrow. He said, "I question whether in the end men will regard that as obscene which is honestly relevant to the adequate expression of innocent ideas, and whether they will not believe that truth and beauty are too precious to society at large to be mutilated in the interests of those most likely to pervert them to base uses." ${ }^{105}$ To see how correct Judge Hand was, we have only to go back to those days when the highest court in Massachusetts banned with the same legal barrier Elinor Glynn's novel Three Weeks and, in 1930, Dreiser's An American Tragedy, despite the best efforts of Arthur Garfield Hayes to defend it. ${ }^{108}$

In the case of Dreiser it took a few years for the decision to fade and for the book to become well accepted throughout the country, including Massachusetts. Today the process is speeded up. It is probably why we have so many reversals in the obscenity field. ${ }^{107}$ At the time the material is considered in the trial court it may be that on the tests then being used, namely the prevailing mores of that local community as interpreted by that court, the material is not ready for acceptance. However, by the time the material goes through the gamut of appeals, the mores of the people catch up to the material and it is no longer obscene. We might note for example that in the 1958 Summerfield ${ }^{108}$ case the trial court was considering a 1954 issue of a nudist magazine. ${ }^{100}$ The Supreme Court decided the same question more than three years later. Who is to say that not much changed except the temper of the times? ${ }^{110}$

\section{The Average Man Test}

The foregoing test of balancing the significant interest of constitutional protection for ideas against the harm caused to those members of the community who are offended by sexual or scatological portrayals does not totally eliminate the problem, but cuts it down to manageable size. However, we must still determine what can be portrayed on

105 United States v. Kennerley, 209 Fed. 119, 120-21 (S.D.N.Y. 1913).

108 See Alpert, Judicial Censorship of Obscene Literature, 52 Harv. L. Rev. 40, 54-55 (1938).

107 For reversals see cases cited, supra notes $1,11,12,18,32,33,56-61,68,71$.

108 Sunshine Book Co. v. Summerfield, 355 U.S. 372 (1958).

109128 F. Supp. 564 (D.D.C. 1955).

110 In State v. Jacobellis, 173 Ohio St. 22, 179 N.E.2d 777 (1962), the defendant was indicted in 1959. The case was argued before the United States Supreme Court on March 26, 1963, and restored for reargument on April 29, 1963. 373 U.S. 901 (1963). It has not yet been reargued. See also State v. Wetzel, 173 Ohio St. 16, 179 N.E.2d 773 (1962), in which defendant was convicted of an obscenity offense committed on February 8, 1960 . The appeals procedure then continued until the conviction was affirmed by the Supreme Court of Ohio. It continued on through the United States Supreme Court. See Wetzel v. Ohio, 371 U.S. 62 (1962). 
television, in newspapers of general circulation, and similar mass media. Here, the only test can be-is the material "patently offensive" to those who know the media well? The effect on the man on the street must be disregarded.

Two recent cases served to raise this issue sharply. In People $v$. Finkelstein, ${ }^{111}$ book store owners were arrested for selling two allegedly obscene books, Queen Bee and Garden of Evil. During trial, defense counsel offered in evidence other publications for sale in adjacent book stores "to indicate . . . the current standard in the community, of literature . . . ." The trial court excluded the evidence because "that is not the way standards are made," and on appeal, the conviction was affirmed. The majority found the exclusion of the evidence proper because the excluded books might be regarded as equally obscene by the "average person" applying contemporary community standards. The Supreme Court of California, however, arrived at a contrary conclusion holding that the exclusion of expert testimony or comparable literature sold in the community was reversible error as a deprivation of due process. ${ }^{112}$

It is interesting that New York and California are following basically divergent views throughout the entire field of obscenity. Since "certain members of the Supreme Court of the United States and experts in the field of obscenity appear to be leaning more and more toward the position that the admissibility of comparable writings and/or expert testimony as evidence of the community standards is a constitutional guarantee," 113 it seems clear that the New York Court of Appeals will again have to accept the reversal of its position by the Supreme Court. ${ }^{114}$

If we accept the proposition that evidence of the state of the art of the medium is permissible, whether by demonstrating comparable material in circulation or by the testimony of the experts in that field, a subsidiary problem arises. What of the case in which the prosecution brings in three experts who testify that in the present state of the art the material is "patently offensive" and the defense counters with four experts who deny the allegation and testify that though the material is new, novel, or experimental, it is not "patently offensive" under all of

11111 N.Y.2d 300, 305, 309, 183 N.E.2d 661, 663-64, 666, 229 N.Y.S.2d 367, 371, 374, cert. denied, 371 U.S. 863 (1962), 12 DE PAUL L. REv. 337 (1963), 76 Harv. L. REv. 1498 (1963).

112 In re Harris, 56 Cal. 2d 879, 366 P.2d 305, 16 Cal. Rptr. 889 (1961).

11312 De Paul L. Rev. 337, 342 (1963).

114 As it was in Kingsley Int'l Pictures Corp. v. Regents of the Univ., 360 U.S. 684 (1959). For a prediction that the Supreme Court will reverse the New York Court in the Tropic of Cancer case see McClure, Obscenity and the Law, 56 Axr. LIBRARY A. Bull. 806, 810 (1962). 
the circumstances? In every such case, assuming that there is honest disagreement among the experts and it is not a sham concocted by the defense, the material should receive the benefit of the doubt. This is entirely in keeping with the underlying function and purpose of the first amendment-to protect the freedom of the communicators to express new and novel ideas. There is presently sufficient drag on experimentation and novelty by sponsors and advertisers who seek to offend no one, so that courts should not add additional restraints. Already inherent in some of our decisions is the thought that suppression of borderline material is a violation of civil liberties. ${ }^{115}$ It is a good thought and deserves Supreme Court enunciation.

\section{OTHERWISE FutILITY}

We have long known that "equity will not perform a futile gesture." ${ }^{116}$ It is submitted that neither should the courts of law. The majority in the New York Court of Appeals which endeavored to suppress Tropic of Cancer was performing a truly futile act. Immediately following Fritch, and continuing up until today, the people of New York were free to purchase the Tropic of Cancer from almost any newsstand or drug store in any metropolitan city in that state. The court's decision ignores the economics and realities of the publication and distribution of books. The decision may slow up the publication of the next similar type of book-not, incidentally, because of fear of punishment, but rather because the publishers foot the bills for the obscenity trials and too many legal controversies cost too much in legal expenses. But once the book has been published, the decision of any court that it is obscene hardly creates a ripple in the distributive process.

In brief, practically all nationally distributed paperback books are published in quantities ranging from 100,000 to $1,000,000$. The publisher turns them over mechanically to a national distributor, who in turn forwards the books to eight hundred local and regional distributors that cover the fifty states. A small distributor in the sparsely settled southwest will have a few hundred local outlets and a metropolitan distributor will have several thousand. Hundreds of new titles are distributed each week in this fashion throughout the country. Once the distributive process has started it is practically impossible for anyone to abort it with respect to a particular title.

115 See In re Louisiana News Co., 187 F. Supp. 241, 247 (E.D. La. 1960), "Defendants [police officials] were after borderline material." Such conduct was found "constitutionally objectionable."

116 See Levine v. Black, 312 Mass. 242, 44 N.E.2d 774 (1942) (denial of an injunction). 
If, conceivably, some crusading attorney-general insisted on interfering because he was armed with an opinion of the appellate court, he might damage the distributional process in his state. But the reading public would suffer the most. The economics of the business is such that if books cannot be distributed mechanically and smoothly through normal channels they cannot be published at all.

Facing this problem squarely we must conclude that when a court declares a specific book obscene and endeavors to remove it from the channels of reading commerce, it is performing an exercise in futility. The point was well stated by the outstanding historian in this field several decades ago when he said, "This business of suppression, usually only one forty-eighth effective at best, puts the judiciary and the vice societies on their sorry nags as a band of Don Quixotes tilting at windmills. The crusades may be fun for somebody but they are not particularly sensible." 117

\section{CONCLUSION}

The time is overdue for our courts, and particularly the Supreme Court, to adopt a fresh approach to the problem of obscenity so that we may have a minimum of interference with the freedom guaranteed by the first amendment and a maximum of certainty so that lawyers and judges can reach intelligent conclusions without the feeling of trying to run in quicksand. To accomplish this, every problem of obscenity must be tested under the criterion of balancing the claim that the material is obscene against the harm to the area of conduct protected by the first amendment. Under this test, nothing is obscene in the abstract. Practically nothing is obscene when it is channelled in the direction of an adult audience on a purely voluntary basis. Material which comes upon us involuntarily as in the newspapers or on television must be screened so as not to insult the large number of people in our midst who are offended. ${ }^{118}$ The courts must make the decisions, but the decisions must be based upon the "patent offensiveness" of the material in the opinions of those who are knowledgeable about the state of the medium. Such decisions must be based upon a clear and indubitable offensiveness. If the industry or art is divided, the material

117 Alpert, Naughty, Nanghty!, in AMerican Library Ass'N, The FIRST FreeDoMr 4, 8 (Downs ed. 1960).

118 The time might come, of course, when so few members of society are offended by nudity, coarse language, and graphic sexual representation that even this form of censorship may be removed. The bikini, modern psychiatric literature, etc., will prevail over the almost superstitious attitudes of the prudish. But until that time the harm to freedom of speech is probably slight compared to the outraged feelings of the "offended" so that in mass media we must continue some limited censorship. 
acquires the protection of the first amendment for it is for this purpose that the first amendment exists.

Finally, the courts must recognize that they are rendering decisions in a dynamic field. That which is decided to be obscene today is accepted tomorrow and becomes a child morality tale the day after. ${ }^{110}$ Courts should not decide cases with an eye to today or even tomorrow or this year. Material which is suppressed should, in the opinion of the court, be that type of material which has little likelihood of acceptance in the immediate coming years. ${ }^{120}$ We must never forget that freedom is only "the absence of chains" 121 and when applying the chains the courts should be slow, selective, and careful.

110 An amusing example is Hawthorne's Scarlet Letter. At first, legally banned, see Haight, Informal Notes on Some Books BanNed for Various Reasons at Varyous Times and IN Various Places 56 (rev. ed. 1955); Clift, Enduring Rights, 28 WILSON LIBRARY BULl. 853 (1954), and called "a brokerage of lust," Commonwealth v. Gordon, 66 Pa. D. \& C. 101, 116 (Ct. Quarter Sess. 1949), it is today on public school reading lists as a morality tale!

120 "It is ironic that the suppressed books in one age in many cases become part of the accepted literature or even the venerated classics of the next. Sometimes the metamorphosis requires generations, sometimes only a few years." EERLICH, Howr. OF THE CENSOR xii (1961). As to fields other than books see Parmelee v. United States, 113 F.2d 729, 731-32 (D.C. Cir. 1940) ; People v. Miller, 155 Misc. 446, 447, 279 N.Y. Supp. 583, 584 (Magis. Ct. 1935) :

Twenty-five years ago women were arrested and convicted for appearing on the beach attired in sleeveless bathing suits, or without stockings. . . . In 1906, the play "Sappho" was suppressed because the leading lady was carried up a flight of stairs in the arms of a man. In 1907, Mary Garden was prevented from appearing in the opera "Salome." ... What was regarded as indecent in the days of the Floradora Sextette, is decent in the days of the fan and bubble dances.

And perhaps, we may add, downright decorous in the days of the bikini.

121 Spitz, Milton's Testament, 13 Antrocr Rev. 290, 292 (1953) : "For freedom strictly defined is still but the absence of chains. It is not the quality of being 'true' or 'false' but simply the quality of being free." 